\title{
NILAI PENDIDIKAN KARAKTER DALAM KUMPULAN CERPEN BATU BETINA KARYA SYARIF HIDAYATULLAH
}

\author{
Ade Hikmat \\ Program Srudi Pendidikan Bahasa dan Sastra Indonesia-FKIP UHAMKA \\ adehikmatns@yahoo.co.id.
}

\begin{abstract}
Abstrak
Penelitian ini bertujuan untuk mengetahui nilai pendidikan karakter dalam kumpulan cerpen Batu Betina karya Syarif Hidayatullah. Untuk mengetahui hal tersebut, maka penelitian ini menggunakan metode deskriptif kualitatif. Hasil penelitian ini menunjukkan bahwa kumpulan cerita pendek Batu Betina karya Syarif Hidayatullah memiliki nilai pendidikan karakter. Nilai tersebut ialah jujur yang terdapat pada cerita pendek Anak Laut dan Bukan Perempuan, nilai tanggung jawab terdapat pada cerita pendek Batu Betina, nilai peduli terdapat pada cerita pendek Sepotong Bulan Coklat Vanila dan Senjayang Temaram Semerah Darah Perbedaan, dan nilai ramah lingkungan yang terdapat pada cerita pendek Lelaki Sunyi di Tepi Kali.
\end{abstract}

Kata Kunci: pendidikan karakter, cerita pendek, pendidikan bahasa.

\begin{abstract}
This study aims to determine the value of character education in the short story collection Batu Betina Syarif Hidayatullah work. To determine this, the research uses descriptive qualitative method. The results of this study indicate that the short story collection Batu Betina Syarif Hidayatullah work has a value of character education. This value is contained in the honest short story AnakLautdatiBukan Perempuan, the value of responsibility contained in the short story Batu Betina, grades matter contained in a short story Sepotong Bulan Coklat Vanila and Senjayang Temaram Semerah Darah Perbedaan, and values that are environmentally friendly in a short story Lelaki Sunyi di Tepi Kali.
\end{abstract}

Keywords: character education,'short stories, language education.

\section{PENDAHULUAN}

Sampai pada kurikulum 2013 digaungkan, pendidikan karakter masih dibicarakan dan bahkan diaplikasikan dalam upaya membangun karakter siswa. Ini terbukti dari komitmen pemerintah dengan memasukkan nilai pendidikan karakter dalam silabus secara lebih pragmatis. Hal ini terlihat dalam silabus di SMA. Secara mendasar, seluruh mata pelajaran, termasuk Bahasa Indonesia menekankan dua aspek kompetensi inti untuk membentuk karakter (afektif dan psikomotorik) dan dua kompetensi inti dalam upaya menanamkan kemampuan kognitif dan psikomotorik.
Hal tersebut terlihat dari kompetensi inti pertama dan kedua di SMA. Pertama, menghayati dan mengamalkan ajaran agama yang dianutnya. Kedua, Mengembangkan perilaku (jujur, disiplin, tanggung jawab, peduli, santun, ramah lingkungan, gotong royong, kerjasama, cinta damai, responsif dan proaktif) dan menunjukkan sikap sebagai bagian dari solusi atas berbagai permasalahan bangsa dalam berinteraksi secara efektif dengan lingkungan sosial dan alam serta dalam menempatkan diri sebagai cerminan bangsa dalam pergaulan dunia.

Kedua kompetensi inti tersebut jika dibandingkan maka akan terlihat suatu garis 
relevan antara pendidikan karakter dalam Kurikikulum Tingkat Satuan Pendidikan (KTSP) dengan Kurikulum 2013. Perbedaan yang sedikit ini, tentu didasari atas situasi yang sosial yang tak jauh berbeda antara kurikulum 2013 dengan kurikulum sebelumnya yang memotori gerakan pendidikan karakter, yakni KTSP.

Situasi sosial yang dimaksud adalah dekadensi moral masyarakat Indonesia pada umumnya, lebih khusus para pelajar yang secara bergantian menghiasi pemberitaan kriminal baik dimedia cetak maupun media televisi. Mulai dari kasus pemerkosaan, pembunuhan, sampai pada problema klasik, tawuran an tar pelajar.

Kini pembelajaran dengan kurikulum 2013 telah diputuskan untuk menggantikan KTSP. Harapan peningkatan mutu pendidikan memuncak. Tidak hanya akademik yang maju, namun juga mampu memperbaiki akhlak peserta didik. Tentu harapan ini merupakan harapan yang membutuhkan jawaban.

Masuknya pendidikan karakter dalam konsep pengembangan kurikulum 2013 merupakan hal yang perlu diapresiasi. Jika menilik pendidikan karakter yang disampaikan Kemendiknas dalam Rohman (2012: 237) terdiri dari delapan belas aspek.Aspek-aspek tersebut terdiri dari: (1) religius, (2) jujur, (3) toleransi, (4) disiplin, (5) kerja keras, (6) kreatif, (7)mandiri, (8)demokratis, (9) rasa ingin tahu, (10) semangat kebangsaan, (11) cinta tanah air, (12) menghargai prestasi, (13) bersahabat/komunikatif, (14) cinta damai, (15)gemar membaca, (16) peduli lingkungan, (17) peduli sosial, (18) tangung jawab.

Meskikompetensi inti di SMA tidak semuanya mencakup delapan belas aspek tersebut, namun ada beberapa aspek yang jika dicermati memiliki istilah yang sama atau hanya sedikit berbeda dengan mencari persamaan istilah lain. Istilah yang senada dengan kompetensi inti terdiri dari, jujur, disiplin, santun, tanggung jawab, peduli, ramah lingkungan, gotong royong (dalam pendidikan karakter versi kemendiknas disebut Demokratis), dan berinteraksi secara efektif (dalam pendidikan karakter versi kemendiknas disebut dengan istilah yang lebih sederhana yakni ber sahabat/komunikatif).

Tidak adanya beberapa pendidikan karakter dalam kompetensi di SMA bisa jadi karena karakter-karakter tersebut telah dipelajari di tingkat satuan yang lebih rendah, seperti di SMP dan SD. Sehingga penanaman nilai pendikan karakter seperti toleransi, kerja keras, kreatif, mandiri, rasa ingin tahu, semangat kebangsaan, cinta tanah air, menghargai prestasi, dan gemar membaca, dianggap tidak relevan untuk SMA. Jika benar keputusan itu diambil berdasarkan pemikiran tersebut, maka sebetulnya akan memunculkan keuntungan dan kerugian. Keuntungannya adalah adanya pemfokusan karakter sehingga dapat berhasil dengan efektif, namun bisa jadi pembilahan semacam itu akan memunculkan pendangkalan lantaran tidak adanya pengulangan mengingat semua butir dalam pendidikan karakter tersebut pastilah akan berkembang sesuai dengan perkembangan fisik dan psikis siswa.

Terlepas dari hal di atas, pendidikan karakter masih memiliki peran yang sentral untuk membangun siswa yang tidak hanya baik dalam prestasi, namun juga baik dalam tingkah laku dan akhlaknya.

Dalam upaya menyampaikan pendidikan karakter, Kemdiknas (2010: 8) menyampaikan perlu adanya rekayasa faktor lingkungan yang dapat dilakukan dengan empat hal berikut: (1) keteladanan, (2) intervensi, (3) pembiasaan yang dilakukan secara konsisten, dan (4) penguatan. Keempat rekayasa tersebut dapat dengan mudah dilakukan dengan cerpen.

Cerpen sebagai sebuah bagian dari karya sastra memiliki sifat mendasar, yakni mimetik (tiruan kehidupan nyata). Hal ini 
memungkinkan melakukan aspek keteladanan lewat alur dan penokohan yang ada dalam cerita pendek tersebut. Misalnya cerpen Aba Marjani yang dimuat di Kompas, menceritakan suatu keteladanan bagaimana kepedulian harus dibangun antar sesama, lewat kisah keluarga yang senang membeli gemblong lantaran kasihan kepada penjualnya yang sudah tua. Diakhir cerita, justru tukang gemblong itu merasa memiliki kewajiban untuk terus berdagang lantaran kasihan pada pelanggan setianya, sampai ketika ajal hendak menjemput ia menyempatkan membuat respe membuat gemblong.

Cerita semacam ini tentu menjadi upaya pembentukan nilai pendidikan karakter peduli selain juga mengajarkan kesantunan bagaimana menghormati orang yang lebih tua. Dengan cerita pendek, siswa diajak untuk berpikir dan meneladani kisah yang dibacanya tanpa guru repot-repot menghadirkan figur untuk diteladani.

Dari cerita pendek tersebut, guru juga memungkinkan untuk melakukan intervensi berupa anjuran untuk peduli antar sesama di akhir pembelajaran. Selain itu, pembiasaan yang dilakukan secara konsisten pun dimungkinkan dengan meninjau perilaku siswa untuk peduli antar sesama dengan menjadikan cerita pendek sebagai penguatan agar mereka selalu ingat dan kembali melakukan akhlak yang baik.

Dengan mengaitkan cerita pendek dalam membangun pendidikan karakter, maka sejatinya upaya ini mencerminkan hubungan simbiosis mutualisme. Di sisi cerpen, cerpen tidak lagi hanya menjadi pelengkap pembelajaran bahasa Indonesia, namun ia kembali ke hakikatnya, yakni menjadi alarm bagi pembacanya. Di sisi pendidikan karakter, cerpen akan membantu penanaman nilai-nilai kepada siswa.

Dari hal tersebut, maka perlu penggalian nilai pendidikan karakter dalam cerita pendek. Dalam hal ini akan dibahas mengenai kumpulan cerpen Batu Betina karya Syarif Hidayatullah.

Berdasarkan latar belakang di atas, maka rumusan masalah penelitian ini adalah bagaimana nilai pendidikan karakter dalam kumpulan cerpen Batu Betina karya Syarif Hidayatullah? Adapun tujuan penelitian ini adalah untuk mengetahui nilai pendidikan karakter dalam kumpulan cerpen Batu Betina karya Syarif Hidayatullah.

\section{Cerpen}

Sejarah sastra Indonesia memiliki tradisi prosa yang cukup lama. Namun demikian, jika dulu panjang pendeknya karangan bukan menjadi persoalan pada pembilahan jenis karya. Biasanya pembilahan didasarkan pada isi,' misalnya untuk hikayat biasanya untuk menyebut karya sastra yang bernuansa Islam dan kerajaan dengan kata-kata yang sifatnya arkeis memenuhi hampir seluruh cerita, namun berbeda dengan fabel yang biasanya berisi kisah tentang hewan yang dapat berbicara, atau cerita rakyat yang biasanya berisi tentang asal-usul suatu daerah.

Kini, pembilahan karya prosa didasarkan pada panjang pendeknya. Jika panjang, karya prosa ini disebut novel dan jika pendek maka kemudian disebut cerpen. Bahkan dalam trend terakhir, muncul cerita pendek yang tidak lebih dari 100 kata yang kemudian disebut fiksimini lantaran perkembangan media sosial (baca: twitter) yang membatasi karakter setiap kali mengunggah.

Dalam menyebut panjang pendeknya karya, biasanya cerpen disebut dapat diselesaikan pembacaannya dalam sekali duduk lantaran cerpen tidak terlalu panjang. Seperti yang disampaikan Suharianto (1982: 39) yang mengungkapkan bahwa cerita pendek adalah wadah yang biasanya dipakai oleh pengarang untuk menyuguhkan sebagian kecil saja dari kehidupan tokoh yang paling menarik perhatian pengarang. Penyajian suatu 
peristiwa yang dapat dibaca selagi kita duduk dan memberikan kesan tunggal bagi pembaca.

$$
\text { Pendapat tersebut, selain }
$$
mengungkapkan bahwa cerpen dapat dibaca dalam sekali duduk. Suharianto juga menyebut cerpen harus menyampaikan kesan tunggal. Hal ini juga yang disampaikan Camby dalam Tarigan (1993: 76).

Kesan tunggal ini, menurut Hardjana (2006: 11) dapat terlihat dari kesatuan tokoh dan kesatuan latar. Selain itu, ia juga menyebut cerpen merupakan karya yang paling sederhana dari cerita fiksi lantaran kesatuan tersebut.Hal senada disampaikan oleh Sumarjo dan Saini (1991: 30) yang mengungkapkan bahwa "cerpen adalah cerita yang berbentuk prosa yang relatif pendek, dikatakan pendek karena hanya mempunyai efek tunggal. Karakter, plot, dan setting yang tidak terbatas, tidak beragam, dan tidak kompleks."

Efek tunggal ini selanjutnya dibangun dalam tiga tahapan. Tiga tahapan tersebut menurut H.B. Jasin dalam Marahaimin (2001: 30) terdiri dari bagian perkenalan, pertikaian, dan penyelesaian."

Dari seluruh definisi tersebut, dapat terlihat bahwa ciri cerpen yang mendasar adalah harus memiliki kesan tunggal. Selain itu, ciri cerpen lainnya adalah dari pendeknya. Pendeknya cerpen menjadi ciri yang zahir dalam membedakan jenis prosa sejenis yakni novel.

\section{Nilai Pendidikan Karakter}

Dalam dekade terakhir Kurikulum Tingkat Satuan Pendidikan (KTSP), nilai pendidikan karakter diinseminasikan ke dalam kurikulum tersebut. Meski tidak terlalu lama, pengembangan pendidikan karakter terus dilakukan,khususnya dalam kurikulum 2013.

Secara definitif, Albertus (2010: 3) mengungkapkan bahwa pendidikan karakter terdiri dari dua kata yang apabila dipisahkan memiliki makna masing-masing.Pendidikan selalu berkaitan dengan hubungan sosial manusia sejak lahir tidak dapat hidup sendiri tetapi membutuhkan orang lain. Hal ini berbeda dengan karakter yang lebih bersifat subjektif. Hal ini karena karakter berkaitan dengan struktur antropologis manusia dan tindakannya dalam memaknai kebebasan.

Mengenai karakter, Samani dan Hariyanto (2011: 43) menyampaikan bahwa karakter dapat dimaknai sebagai nilai dasar yang membangun pribadi seseorang, terbentuk baik karena pengaruh hereditas maupun pengaruh lingkungan, yang membedakannya dengan orang lain, serta diwujudkan dalam kehidupan sehari-hari. Pengertian Samani dan Hariyanto ini paling tidak menjelaskan bagaimana karakter bukan sesuatu yang dibuat-buat, namun karakter merupakan cerminan pribadi dalam tingkah laku. Tingkah laku ini dapat dibentuk baik oleh hereditas maupun pengaruh lingkungan. Sehingga pendidikan karakter merupakan upaya mengajarkan seseorang yang semula tidak memiliki perilaku yang baik, lantas dapat memiliki prilaku yang baik. Prilaku yang baik ini dibentuk oleh pengaruh lingkungan yang ada dalam pendidikan.

Lebih lanjut mengenai pengaruh lingkungan ini, Koesoema (2010:124) menafsirkan pengaruh lingkungan itu sebagai keseluruhan dinamika relasional antarpribadi dengan berbagai macam dimensi, baik dari dalam maupun dari luar dirinya, agar pribadi itu semakin dapat menghayati kebebasannya sehingga ia dapat semakin bertanggung jawab atas pertumbuhan dirinya sendiri sebagai pribadi dan perkembangan orang lain dalam hidup mereka. Atau dalam kata lain, Koesoema menekankan pendidikan karakter pada hubungan yang harus dipertanggung jawabkan dalam relasi antarpribadi.

Secarah lebih jelas, Samani dan Hariyanto (2011: 45) menyebut pendidikan karakter adalah proses pemberian tuntunan kepada 
peserta didik untuk menjadi manusia seutuhnya yang berkarakter dalam dimensi hati, pikiran, raga, serta rasa dan karsa. Pendidikan karakter dapat pula dimaknai sebagai pendidikan nilai, pendidikan budi pekerti, pendidikan moral, pendidikan watak, yang bertujuan mengembangkan kemampuan peserta didik untuk memberikan keputusan baik-buruk, memelihara apa yang baik, dan mewujudkan kebaikan itu dalam kehidupan seharidiari dengan sepenuh hati.

Dari pendapat-pendapat di atas dapat ditarik benang merah, bahwa pendidikan karakter merupakan upaya penanaman nilainilai yang dipengaruhi oleh faktor hereditas dan lingkungan. Pendidikan karakter berhasil jika terdapat perubahan dalam tingkah laku dari buruk menjadi baik. Hal tersebut dapat dilihat dari dimensi hati, pikiran, raga, serta rasa dan karsa.

Dalam menerapkan pendidikan karakter, menurut Foerster dalam Farida (2012: 447) ada empat aspek yang terdiri dari, pertama, pendidikan karakter menekankan sedap tindakan berpedoman terhadap nilai normatif. Siswa menghormati norma-norma yang ada dan berpedoman pada norma tersebut. Kedua, adanya koherensi atau membangun rasa percaya diri dan keberanian, dengan begitu siswa akan menjadi pribadi yang teguh pendirian dan tidak mudah terombangambing dan tidak takut resiko setiap kali menghadapi situasi baru. Ketiga, adanya otonomi, yaitu siswa menghayati dan mengamalkan aturan dari luar sampai menjadi nilai-nilai bagi pribadinya. Dengan begitu, siswa mampu mengambil keputusan mandiri tanpa dipengaruhi oleh desakan dari pihak luar. Keempat, keteguhan dan kesetiaan. Keteguhan adalah daya tahan siswa dalam mewujudkan apa yang dipandang baik. Di sini kesetiaan merupakan dasar penghormatan atas komitmen yang dipilih.

Penerapan yang baik akan memunculkan perilaku yang baik dalam diri siswa. Sehingga pendidikan karakter akan sesuai dengan fungsi yang hendak dicapai. Fungsi pendidikan karakter menurut Kemendiknas (2010: 5) ialah:

1. Pembentukan dan Pengembangan Potensi. Pendidikan karakter berfungsi membentuk dan mengembangkan potensi manusia atau warga negara Indonesia agar berpikiran baik, berhati baik, dan berperilaku baik sesuai dengan falsafah hidup Pancasila.

2. Perbaikan dan Penguatan. Pendidikan karakter berfungsi memperbaiki karakter manusia dan warga negara Indonesia yang bersifat negatif dan memperkuat peran keluarga, satuan pendidikan, masyarakat, dan pemerintah untuk ikut berpartisipasi dan bertanggung jawab dalam pengembangan potensi manusia atau warga negara menuju bangsa yang berkarakter, maju, mandiri, dan sejahtera.

3. Penyaring. Pendidikan karakter bangsa berfungsi memilah nilai-nilai budaya bangsa sendiri dan menyaring nilai-nilai budaya bangsa lain yang positif untuk menjadi karakter manusia dan warga negara Indonesia agar menjadi bangsa yang bermartabat.

Menurut Kemendiknas yangdikutip Rohman (2012: 237-239), terdapat delapan belas sikap yang terdapat dalam karakter kebangsaan. Sikap itu terdiri dari (1) Religius: Sikap dan perilaku yang patuh dalam melaksanakan ajaran agama yang dianutnya, toleran terhadap pelasksanaan ibadah agama lain, dan selalu hidup rukun dengan pemeluk agama lain. (2) Jujur: Perilaku yang didasarkan pada upaya menjadikan dirinya sebagai orang yang dapat dipercaya dalam perkataan, tindakan, dan pekerjaan. (3) Toleransi : sikap dan tindakan yang menghargai perbedaan agama, suku, etnis, pendapat, sikap dan tindakan orang lain yang berbeda dari dirinya. 
(4) Disiplin: Tindakan yang menunjukan perilaku tertib dan patuh pada berbagai ketentuan dan peraturan:

(5) Kerja Keras : Perilaku yang menunjukan upaya sungguh-sungguh dalam mengatasi berbagai hambatan belajar dan tugas, serta menyelesaikan tugas dengan sebaik-baiknya;

Kreatif : Berfikir dan melakukan sesuatu untuk menghasilkan cara atau hasil baru dari sesuatu yang telah dimiliki; (7) Mandiri: Sikap dan prilaku yang tidak mudah tergantung pada orang lain dalam menyelesaikan tugas-tugas; (8) Demokratis : Cara berfikir, bersikap dan bertindak yang menilai sama hak dan kewajiban dirinya dan orang lain; (9) Rasa Ingin Tahu : Sikap dan tindakan yang selalu berupaya untuk mengetahui lebih mendalam dan meluas dari sesuatu yang dipelajari, dilihat dan didengar. (10) Semangat Kebangsaan: Cara berfikir, bertindak, dan berwawasan yangmenempatkan kepentingan bangsa dan negara di atas kepentingan diri dan kelompoknya; (11) Cinta Tanah Air: Cara berfikir, bersikap dan berbuat yang menunjukan rasa kesetiaan, kepedulian dan penghargaan yang tinggi terhadap bangsa, lingkungan fisik, sosial, budaya, ekonomi, dan politik bangsa; (12) Menghargai Prestasi : Sikap dan tindakan yang mendorong dirinya untuk menghasilkan sesuatu yang berguna bagi masyarakat, dan mengakui, serta menghormati keberhasilan orang lain; (13) Bersahabat/Komunikatif: Tindakan yang memperlihatkan rasa senang berbicara, bergaul, dan berkerja sama dengan orang lain; (14) Cinta Damai : Sikap, perkataan dan tindakan yang menyebabkan orang lain merasa senang dan aman atas kehadirian dirinya; (15) Gemar Membaca : Kebiasaan menyediakan waktu untuk membaca berbagai bacaan yang memberikan kebajikan bagi dirinya; (16) Peduli Lingkungan: Sikap dan tindakan yang selalu berupaya mencegah kerusakan pada lingkungan alam yang ada di sekitarnya, dan mengembangkan upaya-upaya untuk memperbaiki kerusakan alam yang sudah terjadi; (17) Peduli Sosial : Sikap dan tindakan yang selalu ingin memberi bantuan pada orang lain dan masyarakat yang membutuhkan; dan (18) Tanggung-Jawab: Sikap dan perilaku seseorang untuk melaksanakan tugas dan kewajibannya, yang seharusnya dia lakukan, terhadap dirinya sendiri, masyarakat, lingkungan (alam, sosial dan budaya), negara dan Tuhan Yang Maha Esa.

\section{METODE}

Dalam penelitian ini, penulis menggunakan metode deskriptif analisis dengan bentuk kumpulan data secara faktual yang terdapat dalam kumpulan cerpen Batu Betina Karya Syarif Hidayatullah dengan objek penelitiannya adalah nilai pendidikan karakter.

Penelitian ini akan berfokus pada empat nilai pendidikan karakter yang berupa jujur, tanggung jawab, peduli, dan ramah lingkungan yang terdapat dalam enam cerpen yang dipilih secara random dari empat belas cerpen yang terdapat dalam kumpulan cerpen Batu Betina karya Syarif Hidayatullah. Keenam cerpen itu ialah, Lelaki Sunyi di Tepi Kali, Batu Betina, Sepotong Bulan Coklat Vanila, Bukan Perempuan, Senjayang Temaram Semerah Darah Perebedaan, dan Anak $1^{\wedge}$ aut.

Instrumen dalam penelitian ini ialah peneliti dan tabel kerja analisis nilai pendidikan karakter dalam kumpulan cerpen Batu Betina karya Syarif Hidayatullah.

\section{PEMBAHASAN}

\section{Jujur}

Jujufmerupakan sifat yang menjadi salah satu aspek untuk meraih kepercayaan. Dalam Islam kata jujur dikenal dengan As-Shidiq. Kejujuran menjadi salah satu faktor mengapa dakwah Rasulullah diterima di tengah 
masyarakat. Sifat jujur inilah yang menjadi salah satu sifat yang wajib bagi rasul.

Secara bahasa, jujur dalam KBBI berarti lurus hati, tidak berbohong. Ini menunjukkan sikap yang harus dilakukan oleh seorang yang jujur adalah dengan berkata apa adanya sesuai dengan fakta. Sifat jujur ini disampaikan dengan nada satir dalam cerpen Anak Laut. Cerpen ini berkisah tentang kehidupan orang pesisir yang keras. Alur cerita ini dibuat seperti karma, dengan pusat penceritaan anak memohon pada orang tua untuk mengajarkan mengaji namun tidak juga diajarkan mengaji dengan berbagai alasan. Tokoh aku dalam cerita ini, selanjutnya memiliki anak, dan kemudian ia pun memarahi anaknya lantaran terus mendesaknya untuk mengajarkan anaknya itu mengaji Al-Quran. Namun setelah ia jadi bapak, barulah tahu alasan mengapa dulu tokoh aku tak diajarkan mengaji oleh orang tuanya: tidak bisa mengaji.

Ketidakjujuran tokoh-tokoh dalam cerita ini memunculkan berbagai konflik, sehingga pembaca diajak untuk merenung bahwa sebuah kebohongan yang dilontarkan akan melahirkan kebohongan-kebohongan lainnya. Oleh karena itu, sebaiknya jujur. Dalam penggalan cerpen ini, kesadaran itu muncul dalam waktu yang terlambat dan bahkan tokoh aku mengalami kesalahan masa lalu yang juga dialami oleh ayahnya,

Aku menutupinya dengan berusaha tak peduli padanya. Namun, tangisnya semakin menjadi-jadi. Tubuhku yang lelah membuatku menjadi pemarah. Aku menjadi begitu geram, gigiku gemerutuk menahan amarah. Tetapi akhirnya pecah juga. Kupukul ia diselangi bentakanku yang cukup keras. la terdiam, kemudian pergi entah ke mana. Aku kembali merebahkan tubuhku, teringat wajah ayah, apakah kau bisa mengaji?

Dalam cerita lain, Bukan Perempuan, kesadaran akan pentingnya kejujuranbenarbenar dipegang oleh tokoh aku. Ia tidak memanfaatkan kesempatan untuk kepentingan pribadi. Kejujuran yang bersumber dari kesadaran yang suci terhadap penafsiran kitab suci. Ia bahkan menghindari peluang besar lantaran ia jujur pada Tuhan bahwa ia bukanlah yang terbaik. Hal ini karena tokoh aku merasa bahwa apa yang dilakukannya, meskipun ia korban pelecehan seksual, ia merasa ia bukanlah orang suci yang bisa dijadikan tuntunan jika kelak menjadi Kyai. Kegundahan ini yang mengemuka sebagaimana dalam pernyataand berikut.

Demikian kutipan surat yang aku terima saat aku bersiap-siap menyapu halaman kamar yang kotor. Aku terima surat itu dengan segala ketakjubanku. Pertama, surat itu dari Shaleha; perempuan yang mampu menggetarkan hatiku. Kedua, Shaleha adalah anak Kyai Mustofa yang sungguh aku tak mengira sebelumnya. Ketiga, Shaleha memilihku menjadi pendampingnya. Ini lebih dari suatu mimpi yang indah. Aku tak pernah membayangkannya. Tetapi entah mengapa surat itu malah membebani diriku. Sebab, pantaskah aku menjadi suami Shaleha?

Aku ingat pergumulanku dengan Ardi. Aku terlalu hina untuk menjadi seorang suami dari anak kyai. Terlalu hina untuk menjadi generasi penerus dari pesantren yang begitu besar namanya ini. Bukan tidak mampu, tapi aku malu. Malu pada kehinaan yang memeras hatiku hampir dalam setiap sujudku.

\section{Tanggung Jawab}

Tanggung jawab merupakan sikap dan perilaku seseorang untuk melaksanakan tugas dan kewajibannya, yang seharusnya dia lakukan. Ketika ia telah melakukan tugas tersebut, maka ia dapat disebut bertanggung jawab. Tanggung jawab sering berafiliasi dengan amanah. Namun, sejatinya hidup itu 
sendiri adalah amanah. Apa yang dilakukan di dunia ini, pada akhirnya dipertanggungjawabkan di akhirat.

Representasi nilai tanggung jawab terlihat pada cerpen Batu Betina. Cerpen ini bercerita tentang seorang ibu yang rela bekerja di tempat hiburan malam untuk membiayai anaknya yang dipesantren serta menutupi biaya pengobatan suaminya yang sakit. Tanggung jawab yang besar dengan pengorbanan yang harus diterima tokoh ibu berupa fitnah dan cacian orang sekitar, diterimanya begitu saja lantaran tokoh ibu yang bernama Basrah merasa benar dengan tidak melakukan hubungan yang melanggar norma agama. Namun, masalah lain muncul ketika anaknya yang menjadi harapan pulang dari pesantren dan turut mencaci pekerjaannya. Anaknya itu bernama Basma. Semula Basma memiliki niat yang kuat untuk membantu ayah-ibunya, namun setelah penolakan diterimanya lantaran pekerjaan ibunya. Ia lantas kecewa dan hendak meninggalkan ibunya. Beruntung diakhir cerita, kesadaran untuk kembali merengkuh tanggung jawab muncul setelah mengalami peristiwa gaib.

"Orang tua Bapak siapa? Biar nanti akan kami hubungi."

"Tarmin... Basrah...," jawab Basma dengan bibir gemetar dan dengan perasaan rindu yang ganjil menyebutkan nama itu.

Penyebutan nama kedua orang tua itu seakan menjadi momentum kesadaran untuk mengakui perjuangan ibunya, mengakui bagaimana tanggung jawab harus dipikul seberat apapun. Di sinilah, nilai tanggung jawab digambarkan tidak mudah untuk dilakukan namun akan memberikan manfaat yang besar.

\section{Peduli}

Peduli merupakan sikap dan tindakan yang selalu ingin memberi bantuan pada orang lain atau orang yang membutuhkan. Hal ini tercermin dalam cerpen Sepotong Bulan Coklat Vanila. Dalam cerpen tersebut diceritakan ketulusan seorang anak kecil yang bernama Putri yang rela memberikan hasil mengamennya untuk orang lain yang sedang kelaparan. Padahal, ia mengamen lantaran hendak membeli sesuatu yang sangat ia sukai yakni coklat. Kepedulian ini sangat menyentuh, sampai Kakaknya heran dan tertegun seperti kutipan berikut ini;

Putri mencari sumber suara. Entah apa yang dipikirkannya? Di Jakarta ini terlalu banyak orang lapar, hingga semua itu terasa sebagai nyanyian. Ya, nyanyian yang cukup pilu untuk didengarkan.

Ternyata suara itu bersembunyi di balik tembok sebuah toko coklat. Dan kami berdua mengenai salah satu dari mereka, pencopet itu!

Putri menatapnya dengan sedih. "Sudah berapa hari kau tak makan?" tanyanya. "Dua," sang adik menjawab. Sang kakak tertunduk malu, mungkin ia juga masih mengingat wajahku dan Putri. "Ini, aku hanya punya ini," ujar Putri sambil memberikan uang yang ingin dibelikan coklat. la tersenyum memberikan apa yang dihasilkannya dengan susah payah hari ini. Sekali lagi, aku tak mengerti dirinya sementara sepotong bulan coklat vanila menantinya dalam etalase.

Kepedulian juga muncul dalam cerita Senja yang Temaram Semerah Darab Perbedaan dalam cerita ini disampaikan bahwa ada seorang laki-laki yang membagikan nasi bungkus hampir setiap hari di sebuah kamp pengungsian. Laki-laki itu membagikan nasi bungkus lantaran penyesalan setelah membunuh sebagian keluarga yang berada di pengungsian itu. Meski pun ia sendiri telah 
banyak kehilangan keluarga lantaran peperangan antar etnis. Namun justru kepedulian lelaki itu membuat takjub tokoh aku dalam cerita ini seperti yang tergambarkan berikut ini:

Entah kenapa aku heran padanya. Tidak biasanya orang membagikan makanan tanpa maksud dan tujuan. Dulu, ketika kami baru mengungsi. Banyak orangorang memberikan bantuan. Kami kira mereka ikhlas. Tapi ternyata tidak! Mereka mengejar popularitas semata! Seiring dengan redupnya berita kami, redup pulalah bantuan yang diberikan kepada kami. Padahal kami masih kekurangan. Teman-teman sekolahku yang mengungsi terpaksa meninggalkan bangku sekolah. Mereka semua berkerja. Buruh, nelayan, bengkel. Ah, hidup memang sulit diterka. Padahal hidup mereka begitu makmur dulu. Di Sampit, Sampit yang penuh petaka, Sampit yang penuh nestapa.

Cerpen ini tidak hanya mencerminkan tentang bagaimana semestinya peduli antar sesama. Namun, cerpen ini turut juga menyentil pembaca bagaimana kepedulian seharusnya dilakukan tanpa pamrih. Suatu tindakan dengan pamrih hanya akan memunculkan kekecewaan.

\section{Ramah Lingkungan}

Ramah lingkungan berarti bagaimana sikap manusia terhadap lingkungannya. Menjaga dan melestarikan lingkungan agar tetap hidup seimbang merupakan salah satu ciri bagaimana ramah lingkungan itu terjadi.

Cerita Lelaki Sunyi di Tepi Kali menyajikan kisah ramah lingkungan tentang bagaimana akibat jika kali (sungai) dihilangkan maka banjir akan datang, meski dibumbui humor yang menggelidk, namun tidak rnenghilangkan pesan yang disampaikan dalam cerita ini. Hal ini seperti tersirat dalam cerita berikut ini,

Namun kini aku tak akan menjumpai lelaki sunyi itu karena sawah dan bahkan kali itu telah tiada, telah rata oleh tanah. Sebentar lagi mungkin akan dibangun perumahan yang memang telah menjamur di kota kami. Hujan masih belum reda, rintik-rintiknya masih terus menari. Sudah semalaman. Mungkin banjir akan segera tiba ke rumah ini.

Aku bersama warga sekitar sepakat bahwa banjir ini terjadi akibat kali kami yang telah tiada, tetapi tidak bagi Badrun dan Sukma, bagi mereka berdua, ini karma!

\section{SIMPULAN}

Nilai pendidikan karakter sangat penting untuk ditanamkan. Penanaman dapat dilakukan dengan rekayasa lingkungan. Salah satu rekayasa lingkungan dapat dilakukan adalah dengan cerita pendek. Dalam kumpulan cerita pendek Batu Betina karya Syarif Hidayatullah terdapat nilai pendidikan karakter. Nilai tersebut ialah jujur yang terdapat pada cerita pendek Anak Laut dan Bukan Perempuan, nilai tanggung jawab yang terdapat pada cerita pendek Batu Betina, nilai peduli terdapat pada cerita pendek Sepotong Bulan Coklat Vanila dan Senja yang Temaram Semerah Darah Perbedaan, dan nilai ramah lingkungan yang terdapat pada cerita pendek Lelaki Sunyi di Tepi Kali.

\section{DAFTAR PUSTAKA}

Albertus, Doni Koesoema. 2010. Pendidikan Karakter: Strategi Membangun Anak di Zaman Global. Jakarta: Gramedia Widiasarana Indonesia.

Farida, Ida. Model Pendidikan Karakter di Perguruan Tinggi: Langkah Strategis Dan Implementasinya Di Universitas. Jurnal Ilmiah Administrasi Publik dan 
Pembangunan, Vol.3, No.l, Januari -Juni 2012, hal 447

Hardjana HP. 2006. Cara Mudah Mengarang Cerita Anak-anak. Jakarta: Grasindo.

Kementerian Pendidikan Nasional. 2010.

Kerangka Acuan Pendidikan Karakter

Tahun Anggaran 2010. Jakarta:

Kementerian Pendidikan Nasional.

Koesoema, Doni. 2010. Pendidikan Karakter.

Jakarta: Grasindo

Marahaimin. 2001. Menulis Secara Populer. Jakarta: Pustaka Jaya.

Rohman, Muhammad. 2012. Kurikulum

Berkarakter. Jakarta: Prestasi Pustaka Publisher.

Samani, Muchlas dan Hariyanto M.S. 2011.

Konsep dan Model Pendidikan

Karakter. Bandung: Remaja Rosdakarya.

Suharianto. 1982. Dasar-dasar Teori

Sastra.

Surakarta: Widya Duta. Sumardjo, Jakob dan

Saini KM. 1991. Apresiasi Kesusastraan.

Jakarta: Gramedia Pustaka Utama.

Tarigan, Henry Guntur. 1993. Prinsipprinsip

Dasar Sastra. Bandung: Angkasa. 